\author{
Soroka T. V., \\ Ph.D. in Philology, \\ Associate Professor at the Department of the English Philology \\ Izmail State University of Humanities
}

\title{
METHODOLOGY AND TECHNOLOGY OF TRAINING BACHELORS OF TRANSLATION AT THE FACULTY OF FOREIGN LANGUAGES
}

Summary. The purpose of the article is to identify the practical and theoretical components in the preparation of training programs and courses on the theory and practice of translation, the practice of foreign languages, linguo- cultural studies and disciplines of specialization. In traditional training, translation was used in the following cases: when studying abstract lexemes or concepts that are difficult to describe or depict; to avoid distracting students' attention with long explanations while reading and listening to unfamiliar texts; when checking the correct understanding of the lexical material; when explaining new grammatical and phonetic phenomena that do not exist in the native language; when repeating the lexical material passed in the previous lessons; when studying synonyms/antonyms and demonstrating different shades of meaning; when introducing idiomatic expressions that cannot be explained or learned without the use of translation; before learning the texts by heart; when comparing the expressive means of language; when assessing students' knowledge in written/oral texts on lexical/grammatical material.

When creating practical courses, one should focus on the making the so-called "through programs", built not only on step-by-step training in language skills, but also on mastering the language culture and traditions. These should be multi-purpose courses focused on achieving the following goals: awareness of the existence of linguistic "pictures" of the world, in particular, of English-speaking countries; understanding of the socio-cultural aspect of learning English, which helps to develop a loyal attitude to the English-speaking culture; understanding the hidden content of the English language as a way of international communication; ability to see differences between native and other cultures (traditions, behavior, etc.) and to perceive them positively; mastering a basic knowledge of socio-cultural values and stereotypes; using socio-cultural knowledge in the process of communication, possession of a sufficient amount of vocabulary on the proposed topic; listening to audio and video materials in order to identify basic information and factual details; preparation for the role of a professional cultural mediator between one's own culture and the culture of the country of the language being studied, as well as effective solutions to problems of intercultural misunderstanding and conflicts.

Key words: translation studies, the language picture of the world, background knowledge, bachelors of translation, competence, through programs.

Problem statement. The problem of assessing the quality of translation has been the subject of research since the first steps of translation practice as a form of communication between languages and cultures. Statements concerning the requirements for translation and the assessment of its quality can be found in ancient thinkers and in the major writers - philosophers who addressed the problems of translation activity. The problem of assessing the quality of translation is at the same time one of the sides of the problem of assessing the quality and effectiveness of human activity as such, which determines the relevance of the development of methods and technologies for training bachelors of translation.

Such a multidimensional approach to the development of professional and linguistic competence of translators is the scientific novelty of the stated question.

Analysis of recent research and publications. Translation problems are at the intersection of interdisciplinary researches in cognitive and social linguistics, cultural studies, translation studies, axiology, and other sciences.

Translation studies is the branch of the humanities dealing with the systematic, interdisciplinary study of the theory, the description and the application of translation, interpreting or both these activities. Translation studies can be normative (prescribing rules for the application of these activities) or descriptive.

According to A.D. Belova, the placement of a person in the center of scientific research - the so-called antprofactor has aroused an increased interest in a number of linguistic problems previously known as the human factor in language, namely, the language personality, the addresser-addressee configuration of the communicative situation, and the language picture of the world (the LPW) [1, p. 18].

The LPW in modern linguistics is often compared to a mirror in which the real world is reflected. However, further development of this problem by scientists shows that the LPW is not more like a mirror, but a self-portrait that the painter creates by looking in the mirror. Thus, the active role of the person in the creation of the LPW is emphasized. Sometimes the LPW is compared to a grid superimposed on our perception, assessment of situations and events [2, p. 49].

We can say that the LPW is the basis of the conceptual picture of the world. The basic concepts, the so-called cultural constants, are normalized in the language and remain immutable. In other concepts that are not universal, such as the concepts of existence, faith, mythology, national specifics are traced; they are marked with a national picture of life. It is the task of cognitive linguistics to show how the same ideas materialize in different languages.

The globalization of world processes, the technologization of the communication space can lead to a change in the LPW and even to their leveling. But, as you know, any language is a form of culture.

In the process of translation, the translator must adapt the author's communicative attitude to the audience's communicative 
attitude from the point of view of cultural diversity. Translation theorists, such as I. Levy [3], believe that the original and the translation perform the same functions in their cultural contexts. The practical problem arises in the different perception of the same phenomena. Pragmatic adaptation, the replacement of associative realities, images, softens the transition from one culture to another. In order to make such an adaptation, the translator needs a certain stock of country-specific background knowledge.

The question of background knowledge is discussed in detail in the book "Language and Culture" by E. M. Vereshchagin and V. G. Kostomarov [4]. Regional knowledge is "the information available to all members of a particular ethnic or linguistic community" [4, p. 126]. Such knowledge is part of the national culture, the result of "the historical development of a given ethnic or state community in equal measure" [4, p. 135]. They "form part of what sociologists call mass culture, that is, they represent information that is certainly known to all members of the national community ...".

Among the country-specific background knowledge, there is also a part of it that has the property of universal prevalence for a given ethnic group or nationality and is called weighted background knowledge.

It is the weighted background knowledge that is of particular importance in the process of teaching foreign languages, as it is a source of selection and the necessary minimization of the country-specific material for teaching purposes. The authors also distinguish between the macrophon, as a set of regional background knowledge of a given language community, and the mini-background - "the volume of background knowledge that the teacher models in the classroom for the perception of a particular work of fiction" [4, p. 165].

Taking into account the theoretical basis of the question, the article aims to consider translation as a multi-valued concept, namely: a tool in learning a foreign language; the process and result of transferring information from one language to another; set of professional knowledge necessary for the bachelors of translation preparing.

The purpose of the article. The purpose of the proposed article is to identify the practical and theoretical components in the preparation of training programs and courses on the theory and practice of translation, the practice of foreign languages, linguo- cultural studies and disciplines of specialization.

The materials of the study are some practical problems and recommendations for solving problems that arose empirically in the learning process.

Research course. Translation is a multi-valued concept, since it involves the process and result of transferring information from one language to another, in this article it is planned to consider translation as an area of professional knowledge necessary for preparing the bachelors of translation.

A translator expert system should contain four areas of knowledge and skills: grammatical competence, sociolinguistic competence, discourse competence and strategic competence.

Grammatical competence embraces knowledge of the rules of the code, including vocabulary, word formation, pronunciation, spelling and sentence structure. Sociolinguistic competence covers knowledge of an ability to produce and understand utterances appropriately in context.

Discourse competence means the ability to combine form and meaning to achieve unified spoken or written texts in different genres.
Strategic competence includes the mastery of communication strategies which may be used to improve communication or to compensate for breakdowns.

R. Bell specified a fifth one - translator's communicative competence: the knowledge and ability possessed by the translator which permits him/her to create communicative acts and discourse which are not only grammatically but socially appropriate [5].

The process of translation (interpreting) is often described for practical reasons as a three-stage pattern $[6 ; 7]$ :

\begin{tabular}{|c|c|c|}
\hline Stage 1 & Stage 2 & Stage 3 \\
\hline $\mathrm{S}_{1 \rightarrow} \mathrm{R}_{1}$ & $\begin{array}{c}\text { CODE SHIFTING } \\
\text { (Transformations) }\end{array}$ & $\mathrm{S}_{2 \rightarrow} \mathrm{R}_{2}$ \\
\hline
\end{tabular}

where Stage 1 is communication between the original sender of information (source language sender or $\mathrm{S}_{1}$ ) and a translator (recipient of information or $\mathrm{R}_{1}$ ), Stage 2 is "code shifting" (transformations and finding equivalents, performed by a translator) and Stage 3 - communication between the translator $\left(S_{2}\right)$ and the final addressee (target language recipient, or $\mathrm{R}_{2}$ ). According to this scheme there are two interrelated communicative acts in the process of translation (interpreting): communication between the initial sender of information and a translator and communication between a translator and the final addressee (recipient or receiver of information). In this process a translator is acting in dual capacity all the time, acting as a recipient (at Stage 1) and as a sender (at Stage 3 ) of the respective messages.

Thus, translation is a process of inter-language and inter-cultural communication when, after special translation analysis of the ST, another communicatively-equivalent text is created in the TL. It is essential to recognize and acknowledge that ST submitted for translation undergoes a number of inter-language changes of meaningful verbal signs.

Singling out and defining a unit of translation is a problem widely discussed in Translation Studies. According to R. Bell, a unit of translation is the smallest segment of a source language text which can be translated, as a whole, in isolation from other segments (as small as possible and as large as is necessary). Should we consider a word as a translation unit? Though there exists the notion of a word-for-word translation, the word can hardly be taken for a translation unit. First of all, this is because word borders are not always clear, especially in English. Sometimes a compound word is written in one element, sometimes it is hyphenated, or the two stems are written separately as a phrase: e.g., moonlight, fire-light, candle light. On the other hand, in oral speech it is difficult to single out separate words because they tend to fuse with each other into inseparable complexes: ['wud ju 'ko:lim?] - according to the stress, there should be two words, while in written speech we can see four words: Would you call him?

Furthermore, it is impossible to consider a phrase (word combination) as a translation unit, because its boundaries are also vague.

Thus, it is not a language unit that should be considered in translation, but a discourse (speech) unit. A translation unit is a group of words united in speech by their meaning, rhythm and melody, i.e. it is a syntagma, or rhythmic and notional segment of speech.

This definition of the unit of translation is process-oriented. If considered from a product-oriented point of view, it can be defined as the target-text unit that can be mapped onto a source-text unit [8].

There are some criteria for classifying translation:

1) The first is based on who does the translation. Nowadays a translation may be done by a human translator or by computer. 
2) Form of speech: according to this criterion, translation as a written form, sight translation (or translation-at-sight, on-sight translation) as the oral translation of written text and interpreting as the oral translation of the oral discourse are differentiated. This criterion also involves subtitling, that is visual translation involving the superimposition of written text onto the screen, and dubbing, or the replacement of the original speech by a voice track which attempts to follow as closely as possible the timing, phrasing and lip movements of the original dialogue.

3) Source text perception: a translator can see or hear the text.

4) Time lapse between the source text perception and translation: consecutive and simultaneous interpreting.

5) Number of languages in translation situation: one-way or two-way translation.

6) Direction of translation: direct translation, that is, translation into the mother-tongue, and inverse translation, or translation into a foreign language.

7) Methods of interpreting: note-taking interpretation, phraseby-phrase interpretation.

8) Functional style and genre of the text: literary works and informative texts.

Depending on the completeness / incompleteness of translation J. Catford (1955) singles out full, partial and total translation [9]. In a full translation the entire text is submitted to the translation process. In a partial translation some parts of the SL are untranslated. Total translation is a translation in which all levels of the ST are replaced by TL material.

Further differentiating translating types J. Catford suggests the term 《restricted translation», by which he means replacement of the SL, textual material by equivalent TL textual material, at only one level.

It is possible to make a translation which is total but in which the selection of TL equivalents is deliberately confined to one rank in the hierarchy of grammatical units, that is rank-bound translation. For the latter an attempt is made to select TL equivalents at the same rank (e.g. words).

Translation as a means of teaching foreign languages hasn't an independent position, since it is impossible to teach all aspects of the language in a complex with the help of translation alone. Nevertheless, translation in teaching and learning a foreign language is in many cases the most effective means of achieving the necessary goal both at the initial, intermediate, and advanced stages of mastering language skills.

In traditional training, translation was used in the following cases: when studying abstract lexemes or concepts that are difficult to describe or depict; to avoid distracting students' attention with long explanations while reading and listening to unfamiliar texts; when checking the correct understanding of the lexical material; when explaining new grammatical and phonetic phenomena that do not exist in the native language; when repeating the lexical material passed in the previous lessons; when studying synonyms/antonyms and demonstrating different shades of meaning; when introducing idiomatic expressions that cannot be explained or learned without the use of translation; before learning the texts by heart; when comparing the expressive means of language; when assessing students' knowledge in written/oral texts on lexical/grammatical material.

The notion "translation" is part of the broader notion of bilingual communication. The main place in it is occupied by language mediation. If we consider the translation process as a professional task of a bachelor translator, then, as already noted, there is a need to adapt the communicative goal of the author of the original text / message in connection with the diversity of culture.

The uniqueness of the current communicative leap lies in the global bilingualism, most often the native language + English [10, p. 14]. The current status of the English language can be described as supralect code corresponding to the culture of the united community. In this regard, the translator is called upon to act as a cultural intermediary.

The structural features and principles of the language are what largely determines how its speakers perceive the world around them and, ultimately, the essence of the entire culture of the people. Linguistics theorist $\mathrm{B}$. Wharf wrote that "speakers of different languages perceive facts and phenomena differently, since these phenomena are expressed and formulated differently in their languages" [11].

This article offers one of the definitions of culture, which seems to be the most successful in terms of the problem under consideration and the needs of translation training.

Culture is a set of material and spiritual values accumulated by a certain community of people, and those values of one national community that are completely absent in another one or significantly differ from them, make up the national socio-cultural fund, which in one way or another is reflected in the language. It is this part of the culture and this part of the language that it is advisable to study in translation studies in order to better understand the original and reproduce information about these source values in the target text using the language of another national culture [12, p. 36].

When creating practical courses, one should focus on the making the so-called "through programs", built not only on step-by-step training in language skills, but also on mastering the language culture and traditions. These should be multi-purpose courses focused on achieving the following goals: awareness of the existence of linguistic "pictures" of the world, in particular, of English-speaking countries; understanding of the socio-cultural aspect of learning English, which helps to develop a loyal attitude to the English-speaking culture; understanding the hidden content of the English language as a way of international communication; ability to see differences between native and other cultures (traditions, behavior, etc.) and to perceive them positively; mastering a basic knowledge of socio-cultural values and stereotypes; using socio-cultural knowledge in the process of communication, possession of a sufficient amount of vocabulary on the proposed topic; listening to audio and video materials in order to identify basic information and factual details; preparation for the role of a professional cultural mediator between one's own culture and the culture of the country of the language being studied, as well as effective solutions to problems of intercultural misunderstanding and conflicts.

In practical terms, to achieve these goals, the existing aspects of teaching a practical English course are being modernized. Old textbooks contain a basic set of traditional knowledge, but do not contain cultural knowledge, and do not appeal to the modern needs of the audience. On the other hand, modern textbooks of English and American publishers, which have appeared in abundance in our book market, are often too entertaining and reviewable, without touching the deep layers of vocabulary and grammatical rules. In addition, they are deprived of such an important aspect in language teaching as translation exercises. This is especially evident in the training of translators. Positive developments include the appearance of sections such as Cultural corner in textbooks containing cultural and background information about the countries of the language being studied. 
As a way of solving this problem, it seems appropriate to highlight such new aspects as Creative writing, Listening and Critical thinking, and Intercultural communication. In the aspect of "home reading", the advantage is given to small genres that are part of a common thematic block with other sections. When developing curricula, the principle of continuity and interaction of theoretical and practical disciplines is proposed, the implementation of which is seen in the combination of the use of practical language skills along with theoretical tools.

Concluding remarks. Working on the translation of any text, oral or written, business or scientific, newspaper or fiction, as well as training a professional translator, always remains a creative process. It requires knowledge of comparable languages, certain skills, and an understanding that language is not only a material form of thinking, not only a means of communication, but also the guardian of all that humanity has learned in the entire history of its existence.

The language has absorbed the culture of the people, and therefore one of the main tasks of the translator is to help one's compatriots to understand other people who have a different language and culture, thus contributing to the dialogue of cultures.

Further research. The prospect of research is to analyze language objectivization English cultural axiological categories presented with words denoting philosophical, world outlook, scientific, social, political, moral, religious, legal, aesthetic values in translation aspect.

\section{References:}

1. Белова А.Д. Языковые картины мира в рамках когнитивно-дискурсивной парадигмы. Культура народов Причерноморья. Симферополь, 2002. №29. С.17-23.

2. Кубрякова Е.С. Части речи с когнитивной точки зрения. Москва : Ин-т языкознания РАН, 1997. 331 с.

3. Левый, Иржи. Искусство перевода. Москва : Прогресс, 1974. 397 c.

4. Верещагин Е.М., Костомаров В.Г. Язык и культура. Лингвострановедение в преподавании русского языка как иностранного. Москва : Изд-во Моск. ун-та, 1973. 233 с.

5. Bell, Roger T. Translation and Translating: Theory and Practice. New York : Longman Inc., 1991. 298 p.

6. Мирам Г.Э., Дайнеко В.В., Тарануха Л.А. Основы перевода: Курс лекций. Учеб. пособ. Киев : Эльга, Ника-Центр, 2002. 248 с.

7. Швейцер А.Д. Теория перевода: статус, проблемы, аспекты. Москва : Наука, 1988. 215 с.

8. The Routledge Encyclopedia of Translation Studies / Ed. by M. Baker, assisted by K. Malmkjer. London \& New York : Routledge, 1998. 654 p.

9. Catford J.C. A Linguistic Theory of Translation: An Essay in Applied Linguistics. London : Oxford University Press, 1965. viii, 103 p.

10. Кабакчи В.В. Основы англоязычной межкультурной коммуникации Санкт-Петербург : РГПУ им. А.И. Герцена, 1998. 232 с.
11. Уорф Б.Л. Лингвистика и логика. Новое в лингвистике. Вып. І. Москва : Прогресс, 1960. С. 173 - 198.

12. Виноградов В.С. Введение в переводоведение (общие и лексические вопросы). Москва : Изд-во ин-та общего среднего образования РАО, 2001. 224 с.

Сорока Т. В. Методика і технологія підготовки бакалаврів перекладу на факультеті іноземних мов

Анотація. Мета дослідження полягає у виявленні практичних і теоретичних складових компонентів під час складання навчальних програм і курсів із теорії і практики перекладу, практиці іноземних мов, лінгвокраїнознавства та дисциплін спеціалізації. У традиційному навчанні переклад використовувався: під час вивчення абстрактних лексем або понять, які важко піддаються опису або зображенню; щоб уникнути відволікання уваги студентів довгими поясненнями в процесі читання і слухання незнайомих текстів; під час перевірки правильності розуміння лексичного матеріалу; під час пояснення на уроках нових граматичних, фонетичних явищ, що не існують у рідній мові; під час повторення лексичного матеріалу, пройденого на попередніх уроках; під час вивчення синонімів та антонімів і демонстрації різних відтінків значення; під час введення ідіоматичних виразів, які неможливо пояснити або вивчити без застосування перекладу; перед розучуванням текстів напам'ять; під час порівняння експресивних засобів мови; під час оцінювання знань студентів у письмових/ усних текстах із лексичного/граматичного матеріалу.

Під час створення практичних курсів акцентовано увагу на розробленні «наскрізних програм», побудованих на поетапному оволодінні мовною культурою і традиціями для досягнення таких цілей: усвідомлення існування мовних «картин» світу, зокрема англомовних країн; розуміння наявності соціокультурного аспекту вивчення англійської мови, що допомагає виробити лояльне ставлення до англомовної культури; розуміння прихованого змісту англійської мови як способу інтернаціональної комунікації; вміння бачити відмінності між рідною та іншими культурами (традиції, манера поведінки тощо) і позитивно їх сприймати; оволодіння базовими знаннями про соціокультурні цінності та стереотипи; використання соціокультурних знань у процесі комунікації, володіння достатнім обсягом словникового складу за запропонованою тематикою; сприйняття на слух аудіо- та відеоматеріалів із метою виявлення основної інформації та деталей фактологічного характеру; підготовка до ролі професійно-культурного посередника між своєю культурою i культурою країни мови, що вивчається, а також ефективного вирішення проблем міжкультурного нерозуміння і конфліктів.

Ключові слова: перекладацькі студії, мовна картина світу, фонові знання, бакалаври перекладу, компетенція, наскрізні програми. 